Doc. dr. sc. Marko Turudić, Pravni fakultet Sveučilišta u Zagrebu

Izv. prof. dr. sc Bosiljka Britvić Vetma,

Pravni fakultet Sveučilišta u Splitu

\title{
DRŽAVA I NAKNADA ŠTETE U VRIJEME PRIRODNIH NEPOGODA - O PRAVNOJ ZAŠTITI I TRANSPARENTNOSTI
}

\author{
$U D K: 347.513: 551.515 .9(497.5)$ \\ DOI: $10.31141 /$ zrpfs. 2021.58 .140 .441 \\ Pregledni znanstveni rad \\ Primljeno: 20. 1. 2021.
}

Prirodne nepogode za sobom ostavljaju nesagledive posljedice: smrt, ozljede i bolesti, ali i značajnu materijalnu štetu. Kako prirodne nepogode u kontekstu naknade štete predstavljaju izvanredne događaje, ne postoji odgovornost države za naknadu tako prouzročene štete svojim građanima. Ipak, država će često, iz solidarnosti sa svojim građanima i u skladu sa svojim mogućnostima, odabrati način naknade bar dijela prirodnom nepogodom prouzročene štete. Država tako može usvojiti i poseban zakon kojim se obvezuje nadoknaditi cijelu ili dio tako prouzročene štete. Ali ako država to odluči učiniti, ima li pravo iz primjene takvog zakona isključiti pravnu zaštitu i transparentnost? Može li tako normirano pružanje pomoći omogućiti nadležnim tijelima djelovanje bez sudskog nadzora i trošenje proračunskih sredstava na netransparentan način? Nažalost, Republika Hrvatska ima iskustva s donošenjem ovakvih posebnih zakona. Najsvježiji primjer potaknut je katastrofalnim zagrebačkim potresom iz ožujka 2020., koji je odnio jedan život, prouzročio brojne ozljede i materijalnu štetu koja se broji u desecima milijardi kuna. Drugi važan primjer potaknut je katastrofalnim poplavama u Gunji iz 2014. Sličnost motivacije za usvajanje tih zakona čini ih idealnim za uspoređivanje zakonodavnih rješenja iz 2014. i 2020., odnosno utvrđivanje kako je (i je li) navedenim zakonima modificirana (uskraćena) mogućnost korištenja pravnih lijekova, odnosno kolika je razina transparentnosti primjene navedenih zakona.

Ključne riječi: odgovornost za naknadu štete, izvanredni događaji, prirodne nepogode, potres u Zagrebu

\section{UVOD}

Izvanredni događaji često za sobom ostavljaju nesagledive posljedice po živote ljudi. Brojne smrti, narušavanje zdravlja, ali i materijalna šteta trajno mijenjaju živote. U tim situacijama nužno je pružiti pomoć i pronaći način kako tu pomoć pružiti najučinkovitije. Učinkovitu pomoć nemoguće je pružiti bez države, štoviše država mora biti predvodnik u pružanju potrebne materijalne i nematerijalne pomoći i u ishođenju (najboljih) modaliteta pružanja pomoći. 
Kao što ćemo videti u radu, država nema nikakvu obvezu naknaditi štetu prouzročenu izvanrednim događajima. Ipak, solidarnost prema vlastitim građanima mora i treba prevladati, te država mora naći način da, u skladu sa svojim mogućnostima, pomoć i pruži. Nažalost, Republika Hrvatska u svojoj je modernoj povijesti imala i previše iskustva sa štetom prouzročenom izvanrednim događajima. Stetom prouzročenom izvanrednim događajima može se smatrati (između ostalog) ratna šteta iz Domovinskog rata, šteta prouzročena poplavama u Gunji iz 2014., te najnoviji primjer štete od prirodne nepogode - potresa u gradu Zagrebu od 22. ožujka 2020.

U svakoj od navedenih situacija, Republika Hrvatska se, neovisno o činjenici da prethodno nije postojala pravna obveza na naknadu štete, odlučila obvezati usvajanjem posebnog zakona kojim se reguliraju svi modaliteti procjene i naknade štete te uklanjanja posljedica štete prozuročene tim konkretnim štetnim događajem. Povod pisanja ovog rada upravo su različiti pristupi u navedenim zakonima, odnosno različiti pristupi u odstupanju od postojećih zakona i postojećih postupovnih rješenja. Naime, nužno se nameće pitanja: mogu li modifikacije pravnog sustava koje takvi zakoni donose biti podloga za ograničavanje ili potpuno onemogućavanje korištenja pravnih lijekova, te može li se takvim zakonima omogućiti nadležnim državnim i javnim tijelima netransparentno postupanje?

Nakon početnog prikaza o specifičnosti štete nastale izvanrednim događajima i pristupa države njenu saniranju, ostatak rada posvetit ćemo analizi dvaju zakona za koje smatramo da su usvojeni kako bi bili temelj saniranja (bar načelno) srodne štete; Zakona o saniranju posljedica katastrofe na području Vukovarsko-srijemske županije ${ }^{1}$ (Zakon o Gunji) i Zakona o obnovi zgrada oštećenih potresom na području Grada Zagreba, Krapinsko-zagorske županije i Zagrebačke županije ${ }^{2}$ (Zakon o Zagrebu).

\section{ODGOVORNOST DRŽAVE ZA ŠTETU I IZVANREDNI DOGAĐAJI}

Odgovornost države za štetu prouzročenu svojim građanima, za razliku od odgovornosti za štetu jednog građanina drugome, povijesnopravno je noviji koncept. Tako se počeci suvremenog shvaćanja odgovornosti države za prouzročenu štetu primjećuju tek u 19. stoljeću. Navedeni razvoj shvaćanja odgovornosti države za štetu nužno je dovesti u vezu s tekovinama Francuske revolucije. Tako Borković naglašava kako se tek paralelno s razvojem pravne države i podvođenja uprave pod načelo zakonitosti osvijestila potreba za uspostavljanje začetaka odgovornosti države za štetu kakvu danas poznajemo. ${ }^{3}$

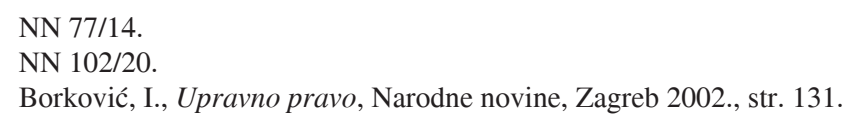


Razvoj odgovornosti države za štetu slijedio je nekoliko etapa. Prva, i vremenski najdulja, bila je etapa potpune neodgovornosti države za štetu. Od sredine 19. stoljeća razvija se shvaćanje da država mora biti odgovorna za štetu koju prouzroči građanima kroz građanskopravne odnose (bez autoritativnog djelovanja) u kojima je država samo jedna ugovorna strana (kupoprodaja, najam i sl.), dok treća etapa kreće nedugo nakon toga (kraj 19. stoljeća). ${ }^{4} \mathrm{U}$ trećoj etapi dolazi do shvaćanja kako država treba odgovarati i za štetu koju je građanima prouzročila svojim autoritativnim djelovanjem, te su se shvaćanja iz te etape zadržala i razvijala do danas. $^{5}$

Kod utvrđivanja odgovornosti države za štetu potrebno je dokazati nastalu štetu, postojanje djelovanja države, ali i uzročnu vezu (kauzalni neksus) između nastale štete i djelovanja države. Važno je napomenuti kako djelovanje države (odnosno njenih službenika) može biti s krivnjom (nezakonito ili nepravilno), ili u potpunosti zakonito. U oba slučaja može doći do obveze države da štetu i nadoknadi. U prvoj situaciji riječ je o odgovornosti države za štetu s greškom, dok je u drugoj situaciji riječ o odgovornosti države za štetu bez greške. ${ }^{6}$

Nausprot ovako općenito prikazanom sustavu odgovornosti države za štetu koja je prouzročena njenim autoritativnim djelovanjem (bilo to djelovanje nezakonito ili zakonito), stoji šteta prouzročena izvanrednim događajima. Ako uzmemo u obzir klasične elemente koji se moraju utvrditi da bi se uspješno mogla tražiti naknada štete od države (prouzročena šteta, djelovanje države i uzročna veza između štete i djelovanja države), kod štete prouzročene izvanrednim događajima nema ni djelovanja države ni uzročne veze između prouzročene štete i djelovanja države. Postoji li onda obveza države da nadoknađuje štetu prouzročenu izvanrednim događajima?

Izvanredne događaje možemo podijeliti na one koji su posljedica prirodnih događaja i na one koji su uzrokovani ljudskim djelovanjem. Tako su prirodno izazvani izvanredni događaji (između ostalog) poplave i potresi, dok su izvanredni događaji izazvani ljudskim djelovanjem rat ili demonstracije i slično. Važno je naglasiti kako općenita normativna definicija izvanrednog događaja ne postoji, već se pojedini događaji u pojedinim zakonima izričito određuju kao izvanredni događaji. ${ }^{7}$ Borković naglašava kako ne postoji odgovornost države da nadoknađuje ovakve oblike štete. U takvim situacijama ne postoje bitni elementi na temelju kojih država inače odgovara za štetu - djelovanje države (njenih službenika) i uzročna veza između tog djelovanja i prouzročene štete. Ipak, država će u ovakvim situacijama često pružati svojim građanima pomoć u nekom obliku. Takva pomoć jest posljedica solidarnosti države sa svojim građanima, te se više može smatrati

4 Ibid., str. 132.

5 Ibid.

6 Na primjer, šteta koja nastane vlasniku domaćih životinja koje su oboljele od zarazne bolesti a koje moraju biti usmrćene sukladno Zakonu o veterinarstvu (NN 82/13, 148/13, 115/18).

7 Marušić, M., „Naknada štete pruzročene izvanrednim događajima“, Pravnik, 41, 2 (85), 2007., str. 96. 
pomoći za saniranje štete nastale izvanrednim događajem, a ne oblikom naknade štete. ${ }^{8}$

Iako pravna odgovornost države ne postoji, država se sama može pravno obvezati na naknadu takve štete. Država će to učiniti usvajanjem zakona.

Nažalost, Republika Hrvatska imala je puno iskustva sa štetom prouzročenom izvanrednim događajima te je usvajala zakone za reguliranje naknade štete prouzročene i izvanrednim događajima uzrokovanim ljudskim djelovanjem i izvanrednih događaja nastalih prirodnim djelovanjem. Tako kao primjere zakona za naknadu štete prouzročene ljudskim djelovanjem možemo navesti Zakon o odgovornosti Republike Hrvatske za štetu uzrokovanu od strane pripadnika hrvatskih oružanih i redarstvenih snaga za vrijeme Domovinskog rata, ${ }^{9}$ kojim se određuje odgovornost Republike Hrvatske za štetu koju su tijekom Domovinskog rata od 17. kolovoza 1990. do 30. lipnja 1996. uzrokovali pripadnici hrvatskih oružanih i redarstvenih snaga u vojnoj ili redarstvenoj službi ili u svezi s tom službom. Također, tu je i Zakon o odgovornosti za štetu nastalu uslijed terorističkih akata i javnih demonstracija, ${ }^{10}$ kojim je propisano kako za tako nastalu štetu odgovara Republika Hrvatska na načelima društvene solidarnosti, ravnomjernog snošenja javnog tereta te pravičnog i brzog obeštećenja. ${ }^{11}$

Što se tiče naknade štete zbog izvanrednih događaja prouzročenih prirodnim djelovanjem, važno je spomenuti Zakon o ublažavanju i uklanjanju posljedica prirodnih nepogoda, ${ }^{12}$ koji je temeljni zakon za naknadu štete kod svih vrsta prirodnih nepogoda. ${ }^{13}$ Uz ovaj opći zakon, iznimno su važna i dva zakona kojima se uređuje naknada štete u slučajevima dva specifična izvanredna događaja uzrokovana prirodnim djelovanjem. Jedan se odnosi na poplavu, drugi na potres. Zakon o Gunji usvojen je 2014. i njime se regulira naknada štete prouzročene katastrofalnim poplavama u Vukovarsko-srijemskoj županiji, dok se novim Zakonom o Zagrebu regulira naknada štete prouzročene potresom u Gradu Zagrebu, Zagrebačkoj i Krapinsko-zagorskoj županiji.

Upravo Zakon o Gunji i Zakon o Zagrebu bit će predmet analize u ovom radu. Naime, smatramo kako su upravo ta dva zakona idealna za analizu (ne)opravdanosti sužavanja ili isključivanja mogućnosti korištenja pravnih lijekova, te ograničavanja transparentnosti djelovanja nadležnih javnih tijela. Oba zakona usvojena su radi utvrđivanja naknade štete uzrokovane prirodnim izvanrednim događajima te, iako

8 Borković, I., op. cit. (bilj. 3.), str. 151.

9 NN 117/03.

10 NN $117 / 03$.

11 Članak 2. Zakona o odgovornosti za štetu nastalu uslijed terorističkih akata i javnih demonstracija.

12 NN 16/19. Taj je zakon izvan snage stavio prethodni Zakon o zaštiti od elementarnih nepogoda, NN 73/97, 174/04.

13 Sukladno članku 3. stavku 2. Zakona o ublažavanju i uklanjanju posljedica prirodnih nepogoda, prirodne nepogode su potres, olujni i orkanski vjetar, požar, poplava, suša, tuča, kiša koja se smrzava u dodiru s podlogom, mraz, izvanredno velika visina snijega, snježni nanos i lavina, nagomilavanje leda na vodotocima, klizanje, tečenje, odronjavanje i prevrtanje zemljišta, druge pojave takva opsega koje, ovisno o mjesnim prilikama, uzrokuju bitne poremećaje u životu ljudi na određenom području. 
je problem koji normiraju relativno sličan, sadrže značajno različita rješenja za vrlo slične probleme.

\section{ZAKON O GUNJI}

U svibnju 2014. poplava katastrofalnih razmjera pogodila je Vukovarskosrijemsku županiju. Neuobičajeno jake kiše uzrokovale su 17. svibnja 2014. puknuće nasipa kod rijeke Save u blizini sela Račinovci i Rajevog Sela. Gunja i navedena sela pretrpjela su i najveću štetu u danima koji su uslijedili. Poplava je, što izravno, što neizravno, uzrokovala smrt petero ljudi, te je iz pogođenih naselja evakuirana 8951 osoba. ${ }^{14} \mathrm{Na}$ više od 7500 objekata privatne i javne namjene zabilježena je šteta veća od 1,2 milijarde kuna, troškovi privremenog smještaja i osnovnih životnih potreba iznosili su više od 13 milijuna kuna, a na usjevima su zabilježene štete od 55 milijuna kuna. ${ }^{15}$

Republika Hrvatska vrlo je brzo krenula s pružanjem pomoći na unesrećenim područjima. Već 20. svibnja 2020. Vlada donosi Odluku o proglašenju katastrofe za područje Vukovarsko-srijemske županije. ${ }^{16}$ Nedugo nakon toga, donosi se niz odluka kojima se usvajaju mjere pomoći unesrećenim građanima. To su Odluka o utvrđivanju bitnog interesa Republike Hrvatske za nabavu roba, usluga i radova u cilju sprečavanja i suzbijanja zaraznih bolesti ${ }^{17}$, Odluka o dodjeli interventnih sredstava za sanaciju šteta na javnim i nerazvrstanim cestama u Republici Hrvatskoj uzrokovanih elementarnom nepogodom,,$^{18}$ Odluka o otpisu dijela zakupnine, naknade za dugogodišnji zakup, naknade za dugogodišnji zakup za ribnjake i naknade za koncesiju za poljoprivredno zemljište u vlasništvu Republike Hrvatske, ${ }^{19}$ Odluka o mjeri pomoći stanovništvu pogođenom poplavom u vezi s izdavanjem osobnih dokumenata, ${ }^{20}$ Odluka o odobravanju pokrića troškova nastalih radi pružanja pomoći stanovništvu izravno pogođenom poplavom, ${ }^{21}$ Odluka o dodjeli robne pomoći iz strateških robnih zaliha za opskrbu i zbrinjavanje stanovništva poplavljenih područja

\footnotetext{
14 https://www.jutarnji.hr/vijesti/hrvatska/najveca-prirodna-katastrofa-u-modernoj-hrvatskoj-evokako-izgleda-gunja-cetiri-godine-nakon-velike-poplave-7350612, pristupljeno 6. kolovoza 2020.

15 Ibid.

16 https://vlada.gov.hr/UserDocsImages//2016/Sjednice/Arhiva//140161\%20-\%201.pdf, pristupljeno 6. kolovoza 2020.

17 https://vlada.gov.hr/UserDocsImages//2016/Sjednice/2014/165\%20sjednica\%20Vlade//165\%20 -\%201.pdf, pristupljeno 6. kolovoza 2020.

18 https://vlada.gov.hr/UserDocsImages//2016/Sjednice/Arhiva//163\%20-\%202.pdf, pristupljeno 6. kolovoza 2020.

19 NN 65/2014.

20 https://vlada.gov.hr/UserDocsImages//2016/Sjednice/Arhiva//163\%20-\%204.pdf, pristupljeno 6. kolovoza 2020.

21 https://vlada.gov.hr/UserDocsImages//2016/Sjednice/Arhiva//163\%20-\%205.pdf, pristupljeno 6. kolovoza 2020.
} 
Slavonije, ${ }^{22}$ Odluka o određivanju Regionalnog centra za prihvat i distribuciju humanitarne pomoći prikupljene za područja ugrožena poplavama ${ }^{23}$ i niz drugih.

Unatoč svim navedenim brzim mjerama koje su normativno imale oblik odluka Vlade, odlučilo se usvojiti i poseban zakon, zbog „opsega i intenziteta nastalih posljedica". ${ }^{24}$ Tako je 26. lipnja 2014. na snagu stupio Zakon o Gunji. Smatralo se kako je Zakon o Gunji nužan jer tada važeća zakonska rješenja (,raštrkana“ u većem broju posebnih zakona) ne odgovaraju potrebama saniranja posljedica poplave. Tako se Zakonom o Gunji uređuje način i postupak donošenja programa, mjera i aktivnosti radi saniranja posljedica katastrofe proglašene na području Vukovarsko-srijemske županije koje je pogođeno poplavom, određuju se nadležna tijela i rokovi za postupanje te druga pitanja s tim u vezi, a s ciljem zaštite života i zdravlja ljudi, zaštite životinja, zaštite imovine, prava vlasništva, zaštite okoliša, prirodnih i gospodarskih dobara, kulturne baštine, kulturne infrastrukture, drugih prava i sloboda te stvaranja uvjeta za uspostavu normalnoga života i obavljanja gospodarskih, obrazovnih i kulturnih djelatnosti. ${ }^{25}$

Zakonom o Gunji propisana su brojna odstupanja od važećih zakonskih tekstova, ali i neka odstupanja od glavnih instituta upravnog prava. ${ }^{26}$ Velika većina tih odstupanja koja su predstavljena Zakonom o Gunji nisu dvojbena - dapače, imaju kao jasan cilj pružiti pomoć javnim tijelima i građanima pri obnovi zgrada, ali i pružiti građanima druge vrste pomoći kako bi se što prije oporavili od svih posljedica poplave. Ipak, nekoliko odstupanja smatramo posebno problematičnim, budući da smatramo kako su onemogućavala korištenje pravnih lijekova te transparentnost u postupanju nadležnih javnih tijela. To se posebno odnosi na odredbu koja izrekom određuje kako akt o obnovi nije upravni akt, te suspenzija primjene Zakona o javnoj nabavi ${ }^{27}$ (ZJN) kod nabave radova i materijala za obnovu zgrada oštećenih ili uništenih poplavom.

\subsection{Pravna priroda odluke o obnovi}

Teorija upravnog prava nema jednoznačnu definiciju upravnog akta. Tako postoje shvaćanja kako je upravni akt svaki akt koji donose državna tijela ${ }^{28}$ (formalna definicija), ali i shvaćanje kako je upravni akt onaj akt kojim se ostvaruje specifična

22 https://vlada.gov.hr/UserDocsImages//2016/Sjednice/Arhiva//163\%20-\%206.pdf, pristupljeno 6. kolovoza 2020.

23 https://vlada.gov.hr/UserDocsImages//2016/Sjednice/Arhiva//163\%20-\%208.pdf, 6. kolovoza 2020.

24 Prijedlog Zakona o saniranju posljedica katastrofe na području Vukovarsko-srijemske županije, s konačnim prijedlogom zakona, https://www.sabor.hr/hr/prijedlog-zakona-o-saniranju-posljedicakatastrofe-na-podrucju-vukovarsko-srijemske-zupanije-s, pristupljeno 6. kolovoza 2020., str. 1.

25 Članak 1. stavak 1. Zakona o Gunji.

26 Vidi, npr., članke 4., 5., 14., 16., 20., 40., 52., 54., 57., 58., 60. Zakona o Gunji.

27 Kako se u radu ne analiziraju odredbe Zakona o javnoj nabavi, nećemo posebno označavati ZJN iz 2011. koji je bio na snazi za vrijeme Zakona o Gunji te ZJN iz 2016. koji je trenutno na snazi.

28 Za detaljnije vidi Borković, I., ,Pojam upravnog akta u francuskoj teoriji upravnog prava“, Zbornik Pravnog fakulteta Sveučilišta u Zagrebu, 51 2001., str. 521., i Borković, I., op. cit. (bilj. 3.), str. 359. 
funkcija države ${ }^{29}$ (materijalna definicija) - shvaćanje koje smatramo ispravnijim. Borković upravni akt definira kao pravni akt kojim, kada je to predviđeno pravnom normom, ovlašteni subjekti, na autoritativan i jednostran način odlučuju o pravima i obvezama pojedinih subjekata u konkretnoj upravnoj stvari. ${ }^{30}$ Iz navedene definicije izvode se glavna obilježja upravnog akta: autoritativnost, jednostranost, konkretnost, pravno djelovanje i pravna vezanost.

Autoritativnost znači da donositelj upravnog akta pri njegovu donošenju nastupa $\mathrm{s}$ autoritetom vlasti, odnosno da pri donošenju upravnog akta dolazi do razlike $\mathrm{u}$ hijerarhijskom položaju donositelja upravnog akta i adresata tog istog akta. ${ }^{31}$ Upravni je akt jednostran zato što nastaje na temelju volje samo donositelja, za razliku od građanskopravnog posla koji nastaje suglasnošću volja dvoje ili više stranaka. ${ }^{32}$ Konkretnost upravnog akta znači da se iz njegove izreke uvijek mora moći točno odrediti na koju se stvar odnosi te na koje se subjekte odnosi. ${ }^{33}$ Pravno djelovanje pretpostavlja da upravni akt proizvodi pravno obvezujuće učinke. To znači da njime neki pravni odnos nastaje, mijenja se ili prestaje (konstitutivni upravni akt), ili se utvrđuje njegovo postojanje (deklaratorni upravni akt). ${ }^{34} \mathrm{Na}$ kraju, jedno od obilježja pravne vezanosti upravnog akta jest da donosilac smije donijeti upravni akt jedino ako je na to ovlašten pravnom normom. ${ }^{35}$

Člankom 20. Zakona o Gunji propisuje se (između ostalog) kako se popravku zgrade, isplati novčanih sredstava umjesto popravka, odnosno uklanjanju zgrade i izgradnji nove zgrade, pristupa na temelju odluke o obnovi koju donosi Ministar graditeljstva. Na kraju članka izričito se navodi kako ta odluka o obnovi nije upravni akt. Dakle, zakonodavac je odlučio navedenoj odluci o obnovi oduzeti svojstvo upravnog akta samoinicijativno, bez ikakvih pravnih argumenata. Stoga smatramo bitnim, sukladno izlaganju o bitnim obilježjima upravnog akta supra, utvrditi ispunjava li odluka o obnovi uvjete da je se smatra upravnim aktom.

U donošenju odluke o obnovi Ministar graditeljstva nastupa s autoritetom vlasti. Činjenica da Ministar graditeljstva kod donošenja odluke o obnovi nastupa $\mathrm{s}$ autoritetom vlasti najbolje se vidi u tome što je donosio i odluke o obnovi kojima su molbe za obnovom odbijane, o čemu će više biti riječi infra. Također, mogućnost donošenja negativne odluke o obnovi ukazuje na činjenicu kako je ta odluka jednostrana, odnosno da se ne donosi na temelju koordinacije volja Ministra graditeljstva i tražitelja obnove zgrade, već isključivo na temelju jednostranog očitovanja volje Ministra graditeljstva. Odluka je o obnovi konkretna, njome se točno određuje obnova koje zgrade se odobrava ili ne odobrava te tko je vlasnik odnosno posjednik predmetne zgrade. Proizvodi i pravne učinke, s obzirom na

29 Borković, I., op. cit. (bilj. 3.) str. 359.

30 Ibid., str. 362.

1 Ibid., str. 360.

32 Ibid., str. 361.

3 Ibid., str. 361.

4 Ibid., str. 361.

35 Ibid., str. 362. 
to da se na temelju odluke o obnovi ,pristupa popravku zgrade, isplati novčanih sredstava umjesto popravka, odnosno uklanjanju zgrade i izgradnji nove zgrade". ${ }^{36}$ Zaključno, odluka o obnovi je i pravno vezani akt, jer je Ministar graditeljstva na njeno donošenje ovlašten upravo Zakonom o Gunji.

Sukladno svemu navedenom, smatramo kako nema dvojbe da odluka o obnovi ispunjava sve teorijske preduvjete kako bi je se smatralo upravnim aktom. Navedeno su neki vlasnici zgrada pokušali dokazati pred provstupanjskim upravnim sudom i Visokim upravnim sudom Republike Hrvatske nakon što je Ministar graditeljstva na temelju njihovih zahtjeva donio negativne odluke o obnovi.

Tako je F. Z. podneskom od 7. srpnja 2016. zatražio od Ministarstva graditeljstva i prostornog uređenja (Ministarstvo graditeljstva) donošenje odluke o obnovi. Ministarstvo graditeljstva ga je dopisom od 13. listopada 2016. obavijestilo kako nisu ispunjeni uvjeti za obnovu navedene zgrade. ${ }^{37} \mathrm{~F}$. Z. ponovno 11. studenog 2016. podnosi podnesak kojim traži donošenje rješenja u svom predmetu. Ministarstvo graditeljstva ga je dopisom od 27. travnja 2017. obavijestilo kako smatra da ne postoje uvjeti za donošenje odluke o obnovi, odnosno rješenja jer, sukladno članku 20. stavku 3. Zakona o Gunji, odluka o obnovi nije upravni akt. F. Z. stoga podnosi tužbu Upravnom sudu u Osijeku (USOS), te navodi kako je odluka o odbijanju obnove upravni akt, te kako predmetni postupak u potpunosti odgovara definiciji upravne stvari sukladno članku 2. Zakona o općem upravnom postupku ${ }^{38}$ (ZUP).

USOS u svojoj presudi od 25. rujna 2017. ${ }^{39}$ u bitnome navodi kako je nužan preduvjet za vođenje upravnog spora da se radi o području upravnog prava, kako kod ocjene zakonitosti pojedinačne odluke kojom je javnopravno tijelo odlučilo o pravu, obvezi ili pravnom interesu, tako i kod propuštanja donošenja te odluke. USOS dalje navodi kako odluka o obnovi sukladno članku 20. stavku 3. Zakona o Gunji nije upravni akt.

Ovdje je potrebna kratka digresija. Naime, ako odlučimo isključivo gramatički tumačiti članak 20. stavak 3. Zakona o Gunji i prihvatimo da odluka o obnovi nije upravni akt, naizgled se može zaključiti kako protiv takve odluke stranka neće imati mogućnost korištenja pravnih lijekova. Ipak, to nije točno. Naime, u toj se situaciji moraju kombinirano primijeniti članci 12., 122. i 156. ZUP-a.

Člankom 12. ZUP-a propisano je kako stranka ima pravo na prigovor protiv upravnog ugovora ili drugog postupanja javnopravnog tijela ili pružatelja javnih usluga. Dalje, člankom 156. ZUP-a propisano je kako osoba koja smatra da joj je drugim postupanjem javnopravnog tijela iz područja upravnog prava, o kojem se ne donosi rješenje, povrijeđeno pravo, obveza ili pravni interes, može izjaviti prigovor sve dok takvo postupanje traje ili dok traju njegove posljedice. Člankom

36 Članak 20. stavak 1. Zakona o Gunji.

37 Kao razlog neispunjenja navodi se činjenica da je u predmetnoj kući u trenutku poplave živjela jedino S. Z. koja je u međuvremenu preminula. Kako F. Z. ne prebiva u navedenoj kući, Ministarstvo graditeljstva tvrdi da nisu bili ispunjeni uvjeti iz članka 12. stavka 4. Zakona o Gunji.

38 NN 47/09.

392 Usl-1124/17-2. 
122. ZUP-a propisana su opća pravila o prigovoru. Tako je propisano da se prigovor podnosi čelniku tijela, koji će o prigovoru odlučiti rješenjem u roku od osam dana od dana izjavljivanja prigovora. Protiv rješenja prvostupanjskog tijela o prigovoru može se izjaviti žalba, a protiv rješenja drugostupanjskog tijela o prigovoru može se pokrenuti upravni spor. Ako nema drugostupanjskog tijela, protiv rješenja tijela o prigovoru može se pokrenuti upravni spor.

Dakle, čak i ako prihvatimo neprihvatljiv stav zakonodavca kako odluka o obnovi nije upravni akt, ona se svakako može i mora podvesti pod „drugo postupanje javnopravnog tijela iz područja upravnog prava", protiv kojeg stranka ima pravo na prigovor, o kojem javnopravno tijelo mora odlučiti upravnim aktom (rješenjem), protiv kojeg se onda može voditi upravni spor.

USOS u predmetnoj presudi zauzima drugačiji stav, pozivajući se na rješenje Visokog upravnog suda Republike Hrvatske (VUSRH) od 4. studenog 2015. ${ }^{40} \mathrm{U}$ tom rješenju VUSRH o tumačenju članka 156. ZUP-a u kontekstu odluke o obnovi navodi samo sljedeće nedovoljno jasno i manjkavo tumačenje: Imajući u vidu cilj $i$ svrhu Zakona o saniranju posljedica katastrofe na području Vukovarsko-srijemske županije, kao i razdoblje za koje je taj Zakon donesen (članak 1. Zakona) postupanje nadležnog ministra u postupku donošenja odluke o obnovi ne podrazumijeva postupanje javnopravnog tijela iz područja upravnog prava o kojem se ne donosi rješenje u smislu odredbe članka 156. Zakona o općem upravnom postupku (Narodne novine, broj 47/09.).

Stoga USOS zaključuje kako s obzirom na to da se u konkretnom slučaju ne radi o postupanju javnopravnog tijela iz područja upravnog prava o kojem se ne donosi rješenje u smislu odredbe članka 156. ZUP-a, ne postoji obveza Ministarstva graditeljstva na donošenje odluke o prigovoru na način predviđen člankom 122 . ZUP-a. Iz navedeng razloga, dalje navodi USOS, Ministarstvo graditeljstva na izjavljeni je prigovor odgovorilo dopisom od 26. travnja 2017. USOS navodi da budući da se u predmetnom postupku ne radi o pružanju zaštite od drugih oblika postupanja javnopravnog tijela iz članka 156. ZUP-a, jer nije ispunjen preduvjet da se radi o području upravnog prava, u vezi s postupkom o obnovi iz članka 20. Zakona o Gunji, nije moguće izjaviti prigovor u skladu s člankom 156. ZUP-a. Sukladno svemu navedenom, USOS je tužbu odbacio.

F. Z. protiv citirane presude podnosi žalbu VUSRH-u, koji svojom presudom od 11. travnja 2018. ${ }^{41}$ žalbu odbija, a u obrazloženju navodi identični paragraf kao onaj citiran supra iz svog rješenja od 4. studenog 2015.

Nakon svega izloženog, postavlja se pitanje zašto je zakonodavac odluci o obnovi „oduzeo" status upravnog akta. Pogotovo kada je to nedvojbeno autoritativana odluka kojom javnopravno tijelo na temelju zakona odlučuje o pravima i obvezama stranke. Nažalost, obrazloženje Konačnog prijedloga Zakona o Gunji ne sadrži nikakvo tumačenje zašto se zakonodavac odlučio za takvu odredbu. Stoga ćemo

40 Usž-1543/15-2.

41 Usž-3603/17-2. 
morati pokušati sami dokučiti koja je bila motivacija zakonodavca za takvim zakonskim rješenjem.

Kako bismo to dokučili, nužno je ustanoviti najvažniju posljedicu uskraćivanja odluci o obnovi statusa upravnog akta. Na taj način ne postoji obveza Ministarstva graditeljstva da odluci o obnovi prethodi upravni postupak sukladno ZUP-u, te stranka u postupku nema postupovna jamstva zaštite svojih prava koja su ZUPom detaljno razrađena. Ipak i sukladno tome, najvažnijom posljedicom oduzimanja odluci o obnovi statusa upravnog akta smatramo činjenicu da tako protiv odluke o odabiru nije dopušteno podnošenje žalbe niti pokretanje upravnog spora. Na taj način zakonodavac je onemogućio bilo kakvu sudsku provjeru zakonitosti postupanja Ministarstva graditeljstva pri donošenju odluka o obnovi.

Ipak, kao što smo već spomenuli supra, primjenom članaka 12., 122. i 156. ZUP-a stranka treba imati pravo podnijeti prigovor protiv postupanja Ministarstva graditeljstva pri donošenju odluke o obnovi, Ministarstvo graditeljstva na takav prigovor mora odgovoriti rješenjem, protiv kojeg bi onda stranka mogla pokrenuti upravni spor. Nažalost, ovakvo tumačenje i primjenu navedenih odredaba ZUP-a onemogućio je VUSRH.

Što je onda krajnja posljedica ovakvog djelovanja zakonodavca i VUSRH-a? Odluka o obnovi ne može biti predmet prigovora, žalbe niti upravnog spora ni pred jednim tijelom niti upravnim sudom, te je Ministarstvo graditeljstva u potpunosti lišeno bilo kakvog preispitivanja svog postupanja u takvim predmetima. Navedene posljedice još je više produbila i suspenzija primjene ZJN-a, o čemu će više riječi biti infra. Stoga smatramo kako su članak 20. stavak 3. Zakona o Gunji, kao i rješenja VUSRH-a, suprotni članku $18 .{ }^{42}$ Ustava Republike Hrvatske. ${ }^{43}$

Nasreću, u svom rješenju od 20. studenog 2018. ${ }^{44}$ Vrhovni sud Republike Hrvatske (VSRH) ispravlja pogrešno stajalište VUSRH-a te navodi sljedeće:

(...) u konkretnom slučaju treba uzeti u obzir i odredbu čl. 122. ZUP-a, čija primjena nije isključena u ovom slučaju. Navedena odredba govori o mogućnosti izjavljivanja prigovora čelniku tijela, a o kojem prigovoru prema st. 3. čelnik tijela odlučuje rješenjem u roku od osam dana od dana izjavljivanja prigovora. $U$ st. 4. je dalje određeno da protiv rješenja prvostupanjskog tijela o prigovoru se može izjaviti žalba, a protiv rješenja drugostupanjskog tijela o prigovoru može se pokrenuti upravni spor. Ako nema drugostupanjskog tijela, protiv rješenja tijela o prigovoru može se pokrenuti upravni spor. Dakle, u konkretnom slučaju prema čl. 12. st. 3. ZUP-a protiv upravnog ugovora ili drugog postupanja javnopravnog tijela ili pružatelja javnih usluga stranka ima pravo na prigovor. Pravilno nižestupanjski sudovi navode da je rješenje povodom prigovora upravni akt, a u tom slučaju je osigurana zaštita pred upravnim sudom.

42 Jamči se pravo na žalbu protiv pojedinačnih pravnih akata donesenih u postupku prvog stupnja pred sudom ili drugim ovlaštenim tijelom. Pravo na žalbu može biti iznimno isključeno u slučajevima određenima zakonom ako je osigurana druga pravna zaštita.

43 NN 56/90, 135/97, 08/98, 113/00, 124/00, 28/01, 41/01, 55/01, 76/10, 85/10, 05/14.

44 Rev 210/2017-2. 
Ipak, praktična važnost ovog rješenja je upitna. Doneseno je u postupku revizije protiv presuda građanskih sudova koji su odbijali nadležnost u postupcima pokrenutima zbog negativnih odluka o obnovi sukladno Zakonu o Gunji. VSRH kao neosnovanu odbija reviziju te sukladno argumentaciji supra naglašava nadležnost upravnih sudova za rješavanje tih predmeta. Nažalost, rješenje dolazi nakon nekoliko pravomoćnih rješenja VUSRH-a sa suprotnom argumentacijom, i nakon prestanka važenja Zakona o Gunji.

\subsection{Suspenzija $\mathrm{ZJN}$-a}

Člankom 5. Zakona o Gunji propisano je sljedeće:

U svrhu saniranja posljedica katastrofe proglašene na području Vukovarskosrijemske županije koje je pogođeno poplavom, odredbe propisa o javnoj nabavi ne primjenjuju se na nabavu robe, usluga i radova čija je procijenjena vrijednost manja od europskih pragova koje Europska komisija objavljuje u Službenom listu Europske unije.

Pragovi iz stavka 1. ovoga članka primjenjuju se na nabavu robe, usluga $i$ radova unutar pojedine zone obnove određene Programom.

Postupci nabava robe, usluga i radova koji se u skladu s propisima o javnoj nabavi provode radi saniranja posljedica katastrofe proglašene na području Vukovarsko-srijemske županije smatraju se iznimno žurnim.

Motivacija zakonodavca za suspendiranje primjene tadašnjeg ZJN-a jako je šturo prikazana u Konačnom prijedlogu Zakona o Gunji s obrazloženjem. Tako se navodi kako „saniranje posljedica katastrofe zahtijeva izuzeće od redovnog propisanog postupka javne nabave", ${ }^{45}$ bez ikakvog artikuliranja zašto baš saniranje posljedica poplave zahtijeva suspenziju ovako važnog zakona. S druge strane, u obrazloženju članka 5. naglašava se kako javnonabavni regulatorni okvir EU-a zahtijeva primjenu javnonabavnih direktiva samo za nabavu u vrijednosti iznad europskih pragova, te napominje kako, iako ce se suspendirati ZJN, za naručitelje postoji obveza poštovanja načela iz osnivačkih ugovora EU-a. ${ }^{46}$

Ovom odredbom zakonodavac je u saniranju posljedica poplave praktički u potpunosti isključio postupke javne nabave. U tom konktekstu važno je napomenuti kako je europski prag za nabavu radova ${ }^{47} 2014$. iznosio 39.046 .431 kunu. ${ }^{48}$ Sukladno podacima samog Ministarstva graditeljstva, obnova svake stambene zgrade iznosila je bitno manje, a teško je zamisliti da je i obnova ijedne zgrade javne namjene koštala preko navedenog europskog praga ${ }^{49}$

45 Op. cit. (bilj. 24.), str. 2.

46 Ibid., str. 24. i 25.

47 Više o nacionalnim i europskim javnonabavnim pragovima vidi u: Turudić, M., Pravo javne nabave, Narodne novine 2017., str. 62-68.

48 Op. cit. (bilj. 24.), str. 23.

49 https://mgipu.gov.hr/UserDocsImages//Sanacija//6.2.2017.Trosak-obnove.pdf, pristupljeno 14. kolovoza 2020. 
Ovakvom suspenzijom ZJN-a u praktički svim postupcima nabave povezanima sa saniranjem posljedica poplave, zakonodavac je omogućio trošenje malo više od 600 milijuna kuna proračunskih sredstava ${ }^{50}$ kroz postupke vrlo slične (praktički identične) postupcima jednostavne nabave, koju karakterizira iznimno liberalan postupovni pravni režim i činjenica da u postupcima jednostavne nabave ne postoji mogućnost podnošenja žalbe Državnoj komisiji za kontrolu postupaka javne nabave (DKOM), kao ni pokretanja upravnog spora. ${ }^{51}$

Dakle, ne samo da gospodarski subjekti koji su sudjelovali u takvim postupcima nabave nisu imali postupovnopravna jamstva koja im je trebao osiguravati i ZUP i ZJN, već im nije bilo omogućeno preispitivati zakonitost tako donesenih odluka o odabiru. Na taj je način zakonodavac, na temelju manjkavo obrazložene potrebe, skoro u potpunosti ignorirao načelo transparentnosti ${ }^{52}$ pri saniranju posljedica poplave. Naime, primjenom ZJN-a osigurava se zavidna razina transparentnosti - kroz javnu objavu poziva za nadmetanje u EOJN, provođenjem javnonabavnog upravnog postupka koji sadrži garancije poštovanja prava gospodarskih subjekata, javnu objavu odluke o odabiru, javnu objavu odluke DKOM-a o žalbi (bez anonimizacije), te javnu objavu presude VUS-a (bez anonimizacije). Ovakva zakonska odredba transparentnost je svela isključivo na podatke koje Ministarstvo gospodarstva samostalno odluči objaviti, što se pokazalo kao iznimno manjkavo rješenje..$^{53}$

\subsection{O posljedicama prikazanih odredbi Zakona o Gunji}

Zakonom o Gunji suspendira se i/ili modificira primjena niza postojećih zakona. Velika većina tih specifičnih rješenja u potpunosti je nekontroverzna te smatramo kako su bila nužna kako bi se unesrećenim građanima pružila brza i odgovarajuća pomoć. Ipak, to ne možemo reći za sva rješenja prisutna u Zakonu o Gunji. To se prije svega odnosi na pravni status odluke o obnovi te suspenziju primjene $\mathrm{ZJN}-\mathrm{a}$, odredbe Zakona o Gunji koje smo odlučili detaljnije analizirati. Nakon izlaganja supra, javlja se pitanje kakve su posljedice ovakva dva rješenja zakonodavca.

Odricanjem statusa upravnog akta odluci o obnovi građanima koji su adresati takvih negativnih odluka onemogućeno je korištenje pravnih lijekova, a takve posljedice dodatno su potvrđene praksom VUSRH-a. Suspenzijom primjene ZJN-a u saniranju posljedica poplave nabavni jepostupak lišen transparentnosti, tijela koja su provodila obnovu i predmetnu nabavu lišena su najvećeg i najvažnijeg dijela vanjske kontrole svog djelovanja, nejasno je po kojim kriterijima su se formirale

50 Ibid.

51 Turudić, M., Pravo javne nabave, Narodne novine 2017., str. 63.

52 O važnosti načela transparentnosti u postupcima javne nabave vidi više u: Turudić, M. Antikoruptivne mjere u novom javnonabavnom regulatornom okviru Europske unije, Fondacija Centar za javno pravo 1/2016., str. 1-11; i Britvić Vetma, B., Ljubanović, B., „Hrvatsko pravo javne nabave usklađenost s pravom EU“, Zbornik radova Pravnog fakulteta Sveučilišta u Splitu, 2/2011.

53 Vidi recimo podatke dostupne na ovoj stranici: https://mgipu.gov.hr/o-ministarstvu-15/djelokrug/ stanovanje-8130/sanacija-poplavljenih-podrucja-8607/8607, pristupljeno 14. kolovoza 2020. 
cijene izvedenih radova, a gospodarski subjekti koji su sudjelovali u postupku također su lišeni mogućnosti korištenja pravnih lijekova.

Dakle, ovakvim rješenjima zakonodavac je onemogućio bilo kakav učinkovit vanjski nadzor nad zakonitošću djelovanja Ministarstva gospodarstva u saniranju posljedica obnove, kao i odgovarajuću razinu transparentnosti pri objavi pojedinačnih troškova obnove. Ministarstvo graditeljstva na svojim je web-stranicama objavilo kako su ukupni troškovi obnove iznosili oko 600 milijuna kuna, ${ }^{54}$ kao i tablicu troškova obnove obiteljskih kuća. ${ }^{55}$ Ipak, nedostaje možda najvažniji podatak koliki su bili troškovi obnove pojedinih kuća po četvornom metru. Stoga ne treba čuditi da je saniranje posljedica poplave izazvalo interes medija. Na medijske upite zašto Ministarstvo graditeljstva nije objavilo pojedinačne troškove obnove i troškove obnove po objektu po metru kvadratnom, državni tajnik u resornom Ministarstvu odgovara kako su tako učinili ,jer smo željeli razdvojiti novac od mještana. Nismo željeli da postoji međusobna zavist koliko je komu uloženo. Važno nam je da je sve kvalitetno napravljeno. ${ }^{"}{ }^{6}$ Dalje su se problematizirale previsoke cijene gradnje nekih septičkih jama, cijene naplaćenog građevinskog materijala, činjenica da je nabavni natječaj za sve radove trajao samo pet dana (s uključenim vikendom!), te praksa gospodarskih subjekata koji su izabrani na natječaju da prepuštaju obavljanje posla obnove kooperantima po značajno nižoj cijeni od cijene ugovorene s državom. ${ }^{57}$

Važno je naglasiti kako je Općinsko državno odvjetništvo u Vinkovcima 2019. zaključilo kako u saniranju posljedica poplave nije bilo nikakvih kaznenih djela. ${ }^{58}$ Ipak, smatramo kako to ne utječe na činjenicu da su ovakva zakonska rješenja eliminirala transparentnost iz obnove, onemogućila strankama i gospodarskim subjektima bilo kakvu pravnu zaštitu, te omogućila Ministarstvu graditeljstva djelovanje bez praktički ikakve vanjske kontrole.

\section{ZAKON O ZAGREBU}

Nedugo nakon potresa počinje se spominjati usvajanje posebnog zakona o obnovi. Tadašnji ministar graditeljstva u medijima naglašava potrebu za što bržim usvajanjem zakona po hitnoj proceduri, te naglašava nužnost suspenzije Zakona o gradnji i ZJN-a, pretpostavljamo upravo zbog velikog naglaska na brzini obnove. ${ }^{59}$

54 https://mgipu.gov.hr/UserDocsImages//Sanacija//Stanje-obnove-16-05-2016.pdf, pristupljeno 15. kolovoza 2020.

55 https://mgipu.gov.hr/o-ministarstvu-15/djelokrug/stanovanje-8130/sanacija-poplavljenih-podrucja -8607/8607, pristupljeno 15. kolovoza 2020.

56 https://www.telegram.hr/politika-kriminal/izvodaci-koje-je-drzava-izabrala-za-obnovu-kuca-u-gunji -naplacivali-visestruko-vise-od-uobicajenih-cijena/, pristupljeno 15. kolovoza 2020.

57 https://www.24sata.hr/news/oderali-su-drzavu-tajni-cjenik-obnove-gunje-nakon-poplava-436333, pristupljeno 15 . kolovoza 2020.

58 http://www.dorh.hr/vink10062019, pristupljeno 15. kolovoza 2020.

59 Vidi npr. https://net.hr/danas/hrvatska/procurili-detalji-zakona-o-obnovi-zagreba-nakon-potresaevo-sto-ce-drzava-sve-financirati-a-sto-pada-na-teret-gradana/, pristupljeno 18. kolovoza 2020. 
Postupak donošenja Zakona o Zagrebu nije išao glatko. Ministar graditeljstva početkom travnja 2020. predstavlja glavne značajke tadašnje verzije nacrta Zakona o Zagrebu, koji je zainteresirana stručna javnost kritizirala ${ }^{60}$ Ta verzija nacrta dijelila je jako puno sličnosti sa Zakonom o Gunji, te je sadržavala skoro sve nedostatke o kojima smo u kontekstu Zakona o Gunji pisali infra.

Ministarstvo graditeljstva nastavilo je s pripremom i doradom nacrta Zakona o Zagrebu. Kako se u svibnju 2020. već moglo očekivati skoro raspuštanje Sabora, nije bilo jasno hoće li Zakon o Zagrebu biti usvojen prije ili nakon raspuštanja. Tako je u jednom javnom nastupu tadašnji ministar graditeljstva bio najavljivao skoro puštanje nacrta Zakona o Zagrebu na e-savjetovanja, s javnom raspravom u trajanju od samo dva do tri dana.$^{61}$ Nasreću, od takvog rješenja se odustalo.

Javna rasprava o nacrtu Zakona o obnovi otvorena je 15. svibnja 2020. te je trajala 30 dana. ${ }^{62}$ Dorađena verzija prijedloga Zakona o Zagrebu upućena je na prvo čitanje u Sabor 27. srpnja 2020. ${ }^{63}$ dok je konačna verzija Zakona o Zagrebu usvojena na izvanrednoj sjednici Sabora od 11. rujna $2020 .{ }^{64}$

$\mathrm{Za}$ analiziranje dostupnosti pravne zaštite i transparentnosti Zakona o Zagrebu, smatramo nužnim analizirati odredbe o pravnoj prirodi odluke o obnovi i novčanoj pomoći, odluka o privremenom smještaju, odredbe o odabiru sudionika u gradnji. Uz navedene $i$, po našem mišljenju, najvažnije odredbe, potrebno je nešto reći i o odredbama o informiranju javnosti.

\subsection{Odluke o obnovi, novčanoj pomoći, stambenom zbrinjavanju i privremenom smještaju}

Člankom 39. Zakona o Zagrebu uređuje se donošenje odluka o obnovi. Naglašava se (inter alia) kako se obnova odnosno uklanjanje zgrada, gradnja zamjenskih obiteljskih kuća, isplata novčane pomoći za privremenu zaštitu zgrade, novčane pomoći za obnovu i novčane pomoći umjesto gradnje zamjenske obiteljske kuće, provode na temelju odluka koje donosi Ministarstvo graditeljstva. Ono što je posebno važno jest činjenica da se izričito navodi da, iako protiv odluke o obnovi i odluke o novčanoj pomoći nije moguće podnijeti žalbu, može se pokrenuti upravni spor. ${ }^{65}$

60 Vidi, npr., https://www.telegram.hr/zivot/strucnjaci-tvrde-ovo-je-7-problematicnih-tocaka-prijedloga -zakona-za-obnovu-zagreba-nakon-potresa/, pristupljeno 28. kolovoza 2020.

61 https://net.hr/danas/hrvatska/stromar-konacno-otkrio-kada-ce-obnova-zagreba-biti-ozakonjenarasprava-ce-trajati-2-3-dana/, pristupljeno 28. kolovoza 2020.

62 https://esavjetovanja.gov.hr/ECon/MainScreen?entityId=14176, pristupljeno 28. kolovoza 2020.

63 https://www.sabor.hr/prijedlog-zakona-o-obnovi-zgrada-ostecenih-potresom-na-podrucju-gradazagreba-krapinsko-zagorske?t=118001\&tid=208796, pristupljeno 28. kolovoza 2020.

$64 \mathrm{https} / / /$ sabor.hr/hr/konacni-prijedlog-zakona-o-obnovi-zgrada-ostecenih-potresom-na-podrucjugrada-zagreba-krapinsko, pristupljeno 1. listopada 2020.

65 Isto rješenje koristi se i za odluku o privremenom smještaju u hitno izgrađenu zgradu za privremeni smještaj sukladno članku 52. Zakona o Zagrebu. 
$\mathrm{Na}$ ovaj je način zakonodavac odluku o obnovi i odluku o novčanoj pomoći neizravno ali nedvojbeno odredio kao upravni akt. Naime, navedenim odlukama svakako ovlašteni subjekt (Ministarstvo graditeljstva), na autoritativan i jednostran način odlučuje o pravima i obvezama pojedinih subjekata u konkretnoj upravnoj stvari. Nadalje, sukladno članku 3. stavku 1. točki 1. Zakona o upravnim sporovima ${ }^{66}$ (ZUS) jedan od predmeta upravnog spora jest i ocjena zakonitosti pojedinačne odluke kojom je javnopravno tijelo odlučilo o pravu, obvezi ili pravnom interesu stranke u upravnoj stvari (upravni akt) protiv koje nije dopušteno izjaviti redoviti pravni lijek. Dakle, neupitna je pravna priroda navedenih odluka kao upravnih akata. Takvim rješenjem zakonodavac je, za razliku od Zakona o Gunji, omogućio sudsku kontrolu zakonitosti djelovanja Ministarstva graditeljstva, odnosno omogućio je građanima kojima su oštećene ili uništene nekretnine u potresu, sudski nadzor zakonitosti odlučivanja o njihovim pravima koja proizlaze iz Zakona o Zagrebu. Ovakva bi odredba stoga mogla imati značajan utjecaj na usvajanje kvalitetnih odluka od strane Ministarstva graditeljstva, ali i na povjerenje građana u zakonito postupanje nadležnih tijela. Također, za razliku od rješenja iz Zakona o Gunji, ovdje nema riječi o neusklađenosti ove odredbe s Ustavom RH.

Važno je istaknuti i kako je odluka o stambenom zbrinjavanju i odluka o privremenom smještaju u postojeće nekretnine izričito određena kao rješenje. Tako je člankom 49. određeno kako se stambeno zbrinjavanje osoba pogođenih potresom i privremeni smještaj tih osoba provode na temelju rješenja koje donosi upravno tijelo Grada Zagreba, Krapinsko-zagorske županije odnosno Zagrebačke županije nadležno za upravljanje stanovima Grada odnosno županije, te da se protiv tog rješenja može izjaviti žalba Ministarstvu graditeljstva. Kako ova rješenja donose tijela niže razine, moguće je protiv njih omogućiti podnošenje žalbe višem tijelu - u ovom slučaju Ministarstvu graditeljstva. Navedeno nije moguće kod odluke o obnovi i odluke o novčanoj pomoći koja je ipak ostavljena u nadležnosti Ministarstva graditeljstva, te je logično da protiv takvih odluka nije moguće podnijeti žalbu (kojem tijelu bi se žalba uopće podnosila?) već isključivo upravnu tužbu.

\subsection{Odredba o odabiru sudionika u gradnji}

Člankom 42. Zakona o Zagrebu propisano je kako se odabir sudionika u gradnji i drugih sudionika u obnovi zgrada, uklanjanju zgrada i građenju zamjenskih obiteljskih kuća obavlja na temelju zakona kojim se uređuje javna nabava prema kriterijima koji se uređuju programom mjera. Također, programom mjera utvrdit će se i najviše cijene usluga, radova i građevinskih proizvoda koje se mogu prihvatiti u obnovi.

Navedenom odredbom izričito se navodi primjena $\mathrm{ZJN}$-a u nabavi dobara, usluga i radova u provedbi obnove Zagreba i okolice. Zato što je tadašnji ministar graditeljstva nedugo nakon potresa navodio kako je u Zakonu o Zagrebu nužno

66 NN 20/10, 143/12, 152/14, 94/16, 29/17. 
suspendirati primjenu ZJN-a jer bi postupci javne nabave znatno usporili obnovu i zato što će jedna od posljedica suspenzije ZJN-a biti da neće biti moguće podnijeti žalbe koje često odugovlače početak radova. ${ }^{67}$

O posljedicama suspenzije ZJN-a kod provedbe obnove pisali smo supra. ${ }^{68}$ Važno je naglasiti da je zakonodavac odustankom od prethodnih najava o suspenziji ZJN-a odbio ponoviti greške iz Zakona o Gunji, te odustao od „hitnosti” kao opravdanja ne samo za preuranjeno i netransparentno (bilo je predviđeno samo nekoliko dana javne rasprave!) donošenje zakona, već i za neopravdano i neobrazloženo eliminiranje kontrole zakonitosti odluka o odabiru zbog ,hitnosti i brzine” obnove. Ovako je zakonodavac možda i na najznačajniji način utjecao na visoku razinu transparentnosti i predvidivosti primjene Zakona o Zagrebu. Naime, ovako gospodarski subjekti podnose svoje ponude sukladno zakonu s kojim su već upoznati, te uživaju postupovna jamstva i ZUP-a i ZJN-a. Također, osigurava im se mogućnost neovisne kontrole odluka o odabiru, i to u dva stupnja (DKOM i VUS). To je posebno važno i zbog zakonskih obveza iz ZJN-a koje osiguravaju transparentnost; javna objava poziva za nadmetanje u EOJN, provođenje javnonabavnog upravnog postupka koji sadrži garancije poštovanja prava gospodarskih subjekata, javna objava odluke o odabiru, javna objava odluke DKOM-a o žalbi (bez anonimizacije) te javna objava presude VUS-a (bez anonimizacije).

\subsection{Informiranje javnosti}

Člankom 5. stavkom 12. Zakona o Zagrebu propisano je kako cee Ministarstvo graditeljstva, Fond za obnovu i nositelji obnove za zgrade javne namjene redovito i u cijelosti informirati javnost o aktivnostima i troškovima obnove sukladno propisima iz područja prava na pristup informacijama te će u mrežnu aplikaciju Ministarstva graditeljstva redovito i u cijelosti unositi potrebne podatke i kvartalno objavljivati podatke o utrošku sredstava svih nositelja obnove.

Navedenom odredbom ne stvaraju se nove obveze navedenih javnih tijela, već se samo dodatno naglašavaju obveze koje već postoje sukladno Zakonu o pravu na pristup informacijama ${ }^{69}$ (ZPPI). Važno je napomenuti kako je prva verzija ove odredbe prvi put uključena u verziju zakona iz svibnja 2020., u kojoj je bilo navedeno kako će se odabir sudionika u gradnji i drugih sudionika na obnovi zgrada, uklanjanju zgrada i građenju zamjenskih obiteljskih kuća obavljati na temelju javnog poziva - dakle bez primjene ZJN-a. U takvoj situaciji smatrali smo da je ovakva odredba nedovoljno jamstvo transparentnosti, odnosno da nikako ne može

67 Za više detalja vidi https://upravnopravo.blog/2020/03/31/suspendirajmo-zjn-sto-je-najgore-stose-moze-dogoditi/, pristupljeno 31. kolovoza 2020.

68 Vidi i Turudić, M., „Public Procurement and Natural Disasters - Lessons from Croatia“, European Procurement and Public Private Partnership Law Review 2/2020.

69 NN 25/13, 85/15, vidi posebno članak 10. ZPPI-a. 
nadomjestiti usporedno visoku razinu transparentnosti koju jamči ZJN. ${ }^{70}$ Kako Zakon o Zagrebu ipak ne suspendira ZJN, više se ne može govoriti o ovoj odredbi kao o nadomjestku za transparentnost koju jamči ZJN, već kao o korisnoj nadopuni.

\section{ZAKLJUČAK}

Država nema prethodnu obvezu nadoknađivati štetu nastalu izvanrednim događajima. Ipak, država će gotovo uvijek iz solidarnosti sa svojim građanima pružati neki oblik humanitarne pomoći, ali i naknade tako prouzročene štete. Država se također može i pravno obvezati nadoknađivati takvu štetu, a to će činiti usvajanjem posebnih zakona kojima će odrediti na koji način, pod kojim će uvjetima i u kojem obujmu tako nastalu štetu nadoknađivati.

Takvi posebni zakoni često će biti potrebni s obzirom na to da specifičnosti individualnih izvanrednih događaja zahtijevaju specifična normativna rješenja kako bi se građanima moglo pomoći na najbolji mogući način. Ipak, do koje granice se ta specifična rješenja može tolerirati? Navedeno pitanje nužno se postavlja analizom Zakona o Gunji, posebno odredaba o pravnoj prirodi odluke o odabiru i suspenzije primjene ZJN-a. Same te odredbe i posljedice njihove primjene u potpunosti su neprihvatljive. Navedenim je odredbama suspendirana pravna zaštita u primjeni navedenog zakona, te je transparentnost postupanja nadležnih tijela dovedena na nepotrebno nisku razinu.

Nažalost, odmah nakon zagrebačkog potresa počele su se javljati naznake kako bi i poseban Zakon o Zagrebu trebao dijeliti mnoge sličnosti sa Zakonom o Gunji. Iako su i predmetna poplava i potres prirodne nepogode i izvanredni događaji, materijalna šteta koju su prouzročili jest neusporediva. Procijenjena vrijednost materijalne štete nakon poplava u Gunji i okolici iznosila je oko 1,7 milijardi kuna, ${ }^{71}$ dok je zadnja procijenjena vrijednost materijalne štete nakon potresa u Zagrebu oko 86 milijardi kuna. ${ }^{72}$ Da je i Zakon o Zagrebu sadržavao slična rješenja kao i Zakon o Gunji, vjerujemo kako bi tako prouzročena šteta bila nesaglediva.

Stoga treba pozdraviti usporediva normativna rješenja u Zakonu o Zagrebu. Tim rješenjima izbjegnute su greške iz Zakona o Gunji. To se prije svega odnosi na mogućnost korištenja pravnih lijekova i za adresate odluka o obnovi, ali i za gospdoarske subjekte koji neće biti odabrani ponuditelji u postupcima nabave radova, dobara i usluga u obnovi. Također, provođenje postupaka javne nabave (iako ne bez svojih posebnih mana) neusporedivo je otvorenije i transparentnije rješenje od onoga na temelju kojega se provodila nabava za potrebe saniranja posljedica poplava iz 2014.

70 https://upravnopravo.blog/2020/05/18/prijedlog-zakona-o-obnovi-o-transparentnosti-i-postupkunabave/, pristupljeno 31. kolovoza 2020.

71 https://www.jutarnji.hr/vijesti/hrvatska/od-katastrofalnih-poplava-proslo-je-pet-godina-gunja-jesad-jos-ljepsa-ali-nema-posla-ni-ljudi-8884607, pristupljeno 2. rujna 2020.

72 https://vlada.gov.hr/vijesti/steta-od-potresa-u-zagrebu-86-milijardi-kuna-vlada-uputila-zahtjevza-sredstva-iz-fonda-solidarnosti-europske-unije/29700, pristupljeno 2. rujna 2020. 


\section{THE STATE AND DAMAGES DURING NATURAL DISASTERS - ON LEGAL PROTECTION AND TRANSPARENCY}

Natural disasters leave behind them immeasurable consequences: death, injury, and disease as well as considerable material damages. As natural disasters in the context of damages represent extraordinary events, there is no state liability for compensation for citizens from such caused damage. However, the government often, out of solidarity to its citizens, and in keeping with their means, choose the compensatory measure for at least a portion of the damage. The State can so adopt a special law by which it commits to compensate the entire damage or a portion of it. However, if the government chooses to do so, does it have the right from the application of such law to exclude legal protection and transparency? Can assistance normed in such a way enable authorized bodies to act without court supervision and spend public budget money in a non-transparent way? Unfortunately, the Republic of Croatia has experience with passing such special laws. The most recent example was with the catastrophic earthquake in Zagreb in March 2020 which took one life, caused numerous injuries and material damage costing tens of billions of Kuna. The other important example resulted from the catastrophic floods in Gunja in 2014. Similar motivation for adopting such laws makes them ideal for comparison with legislative solutions from 2014 and 2020, that is, establishing how (and whether) the stated laws modify (deny) the possibility of using legal remedies, that is, what is the level of transparency in the application of the afore stated laws.

Key words: liability for damages, extraordinary events, natural disasters, earthquake in Zagreb 